\title{
Pleomorphism and Germ Terrain Dualism
}

\author{
Mister Seun Ayoade* \\ BSc (Hons) Physiology, University of Ibadan, Oyo State, Nigeria
}

Submission: June 19, 2018; Published: June 25, 2018

*Corresponding author: Mister Seun Ayoade, BSc (Hons) Physiology, University of Ibadan, P.O. Box 22325, Oyo State, Nigeria, Email: SeunAyoade@protonmail.com

\section{Opinion}

The Germ-Terrain duality theory of disease states that the aetiology of certain diseases/diseased states is better explained as a complex interplay between germs and the anatomical/ physiological integrity of the body cells [1]. It argues that the aetiology of certain diseases is not fully explained merely by the presence of germs (Germ Theory) or by a mere loss of cellular integrity (Terrain Theory). As a result, the prevention and treatment of such diseases should focus not just on fighting germs but on maintaining/restoring the anatomical/ physiological cellular integrity. The Germ-Terrain duality theory is a harmonization of the current Germ Theory (popularized by Louis Pasteur) and the hitherto discarded Terrain Theory (popularized by Pierre Bechamp) [1]. Pleomorphism is defined as having more than one shape or having several shapes and forms [2]. According to the subject matter of this mini discourse, pleomorphism is the phenomenon whereby a microscopic entity/ individual microscopic entity assumes a number of different forms, for example during its life cycle [3]. It is not farfetched to state that without pleomorphism there would be no germ terrain dualism, or that without germ terrain dualism there would be no pleomorphism. Pleomorphism and germ terrain dualism are as inseparable as water and wetness, and regarded to be as factual as the transition of water to ice or ice to water vapour/ mist. That pleomorphism occurs is not a great controversy today. The great controversy is the extent to which it occurs- and the implication for disease aetiology and the current germ theory. According to the GTD theory, the basic unit of living this is the microzyma (otherwise called cellular dust) [4] and not the cell. Microzyma are like the currency of germ terrain dualism and associated pleomorphism. The complex interplay between germs and the anatomical/physiological integrity of the body cells is best understood in the light of the microzyma, as elucidated by Professor Pierre Bechamp [5] viz:

(a) The microzymas of the animal organism proceed from the vitellin microzymas, which are autonomous anatomical elements in the vitelllus. (b) The number of anatomical species of microzymas is enormous

(c) The essential biological characters of the microzymas are to be creators of cellules by synthesis and of vibrioniens by evolution.

(d) The physiological and chemical characters of microzymas are to produce the zymases and to be themselves ferments having a determined form.

(e) From the fact that a microzyma may become a vibrionen by evolution, it necessarily follows that the species of microzymas being innumerable the species of vibrionens are likewise innumerable.

(f) It is further important to remember that an anatomical element microzyma is animal in an animal, vegetable in a vegetable. Hence arises this question: to what kingdom belongs the bacterium of such or such an animal or vegetable microzyma?.

(g) We must remember that any microzyma, before it accomplishes the evolution (i.e. pleomorphism) which produces a bacterium, passes through the evolutionary phases of microzyma slightly changed in form, of microzyma successively associated in twos, in threes, then in several grains etc.

(h) An anatomical element, microzyma, in a plant or in an animal, whose conditions of existence have just changed, can become a bacterium by evolution (pleomorphism), and the intermediate evolutionary phases, like those of the tadpole, which becomes a frog, leaves the special nature of the microzyma still existing; there are not new species. The perfect bacterium depends on the nature of the microzyma, as the perfect batrachian depends on the particular nature of its tadpole.

(i) Every bacterium resolves itself by spontaneous destruction into microzyma, and the microzyma thus evolved 
("pleomorphed") are different from the anatomical microzyma which has become a bacterium, not morphologically, nor functionally so far as regards being a figured ferment, but by a collection of properties, which assure the perennity of the form and of the function in a condition of individual separateness.

(j) The microzymas have been constituted physiologically imperishable!

(k) The microzymas are organized living beings, of a class apart, without analogue.

(l) Death can be defined as the absolute de-coordination of the function of the microzymas.

\section{References}

1. Mister SA (2017) Antimalarials Validate the Germ Terrain Duality Theory. JOJ Nurse Health Care. 2(5): 555600.

2. (2009) UN Panda Coincise Pocket Medical Dictionary ( $\left.2^{\text {nd }} e d n\right)$, Jaypee Brothers Medical Publishers, India, p. 493.

3. Oxford Mini Dictionary for Nurses ( $5^{\text {th }}$ edn), Oxford University Press, UK, p. 495.

4. Mister SA (2017) Koch's Postulates and Germ Terrain Dualism; Cellular Dust as Yet another Term for Microzymas. JOJ Nurse Health Care 5(4): 555666 .

5. A. Bechamp, Kessinger Legacy, Blood and Its Third Anatomical Element. Pp. 200-203, 217-218,

Your next submission with Juniper Publishers will reach you the below assets

- Quality Editorial service

- Swift Peer Review

- Reprints availability

- E-prints Service

- Manuscript Podcast for convenient understanding

- Global attainment for your research

- Manuscript accessibility in different formats

( Pdf, E-pub, Full Text, Audio)

- Unceasing customer service

Track the below URL for one-step submission https://juniperpublishers.com/online-submission.php 